\title{
THE IMPORTANCE OF COMPETITIVENESS MEASURING IN THE LIGHT OF SERBIA'S ACCESSION TO EUROPEAN UNION
}

\author{
*Andrea KATIĆ \\ **Saša RALETIĆ \\ ***Gordana ABRAMOVIĆ \\ **Bojana JOKANOVIĆ \\ *Educons University, Serbia \\ **University of Novi Sad, Serbia \\ ***University of Maribor, Slovenia
}

\begin{abstract}
The 2000 Lisbon European Council defined competitiveness as the main strategic goal and prerequisite for sustainable economic growth, high employment and social cohesion. However, the economic crisis encouraged the adoption of the new strategy called "Europe 2020" to ensure new impetus for dynamic and sustainable growth, reemphasizing competitiveness as the main tool for growth as well as an important issue within macroeconomic surveillance. Considering that Serbia wants membership in European Union, foundations on which EU is built and current goals must be the direction in which development of Serbia should be steered. Mean for that is the strategic document entitled "Serbia 2020" defining the basic elements of socio-economic development of Serbia until the year of 2020. It follows the structure proposed and adopted by the European Commission, taking into account the specific conditions of the Republic of Serbia. In accordance to that, this paper will present overview of the most important competiveness indexes. It will include detailed analysis of Serbia low ranking and possible ways for improving its competiveness. The paper will consider different strategies for better monitoring of level of competitiveness of Serbia. It will also benchmark different competiveness indicators with targets of EU strategies, especially Europe 2020.
\end{abstract}

Keywords: European Union, European enlargement, national competitiveness, competitiveness measuring, Serbia's accession

\section{INTRODUCTION}

The global importance of the concept of competitiveness has increased rapidly in the recent years, with the issues surrounding it becoming, at the same time, both more empirically refined and theoretically complex. It was the research of Porter (1990) that first defined national competitiveness as an outcome of a nation's ability to innovate in order to achieve, or maintain, an advantageous position over other

nations in a number of key industrial sectors. Therefore, measuring, understanding and analyzing competitiveness has become a vital factor in creating an environment policy. Nowadays, there are many complementary studies that produce composite indices of economic competitiveness.

In the case of Serbia, membership in the European Union represents an opportunity for stable development and rise of national competitiveness. Considering the fact that Serbia in this period of time puts all its forces to achieve objectives from Association Agreement, question is how and in which way this process will affect national competitiveness of Serbia. Does it mean that Serbia is more competitive if the county is closer to EU membership? What are all possible ways for monitoring Serbia's development?

\section{SERBIA'S ACCESSION TO EUROPEAN UNION}

European Union originated Process of stabilization and association (PSA) for the countries of Western Balkan, which aim is stabilization of the whole region, as a post-conflict region, and opening of the perspective of membership in EU. Aim of the Process of stabilization and association is creating stronger political and economic relationships between countries which are in the process of entering 
European Union, as a main economic force of the continent. Aim is elimination of sources of radicalism in those countries which were the basic reason of wars during ' $90-\mathrm{s}$ of $20^{\text {th }}$ century by stabilization of economic situation in the countries of Balkan. Process of stabilization and association represents basic outline for relations of the countries of Western Balkan and EU by the time of their accession to EU. Beside Serbia, in the Process of stabilization and association are also engaged Croatia (has status of a candidate for the membership in EU and has begun negotiations about membership), Macedonia (has status of a candidate and is waiting for the beginning of negotiations about membership), Albania (submitted questionnaire), Montenegro (has status of a candidate and is waiting for the beginning of negotiations about membership) and Bosnia and Herzegovina (has status of a potential candidate). European Union guarantied European perspective to all the countries of Western Balkan on the Summit in Salonika 2003, emphasizing that these countries will be entering membership in EU separately, regarding speed of the progress of reforms, and not as a group (Mirkovic, 2009).

There are three basic elements of the Process of stabilization and association: Agreement about stabilization and association, politics of conditioning defined by EU as a part of Criteria from Copenhagen which are used to define conditions for membership in EU and economic and financial help which EU provides to countries in process through pre-acceding funds (CARDS, ISPA and SAPARD until year 2006. and IPA fund in time period 2007-2013). Key element of this process is conclusion of Agreement about stabilization and association (ASA) which will define relations between EU and the country that signs it until the moment of its entrance into membership of EU. Politics of conditioning refers to fulfillment of criteria from Copenhagen, accepted in the year 1993 on the summit of EU in Copenhagen, which are used to define conditions for membership in EU. Then were defined three criteria countries need to fulfill to become a member of EU:

-Political criteria (existence of democracy and reign of rights, respect of human rights and respect of rights of minorities, stability and functioning of institutions),

-Economic criteria (tenable and functional market business life has to exist, capable of withstand the competition on European market) and

-Legal criteria: country has to have ability of resuming and respect of obligations deriving from membership in EU (acceptance of acquis communautaire and to exist administrative capacity for usage of acquis communautaire, administrative and judicial).

Republic of Serbia is today country potential candidate for membership in European Union and is on social and economic turning point which brings new opportunities and their challenges. That turning point requires overview of own social and economic advantages, but also identifying shortages and weaknesses that are detaining us in full utilization of opportunities that are opening for Serbian business and society.

Strategic course of Serbia is integration in EU and entering European and world market of domestic companies and business in competition of high number of successful, export-oriented companies from

other countries, multinational companies with world known products - brands, modern organized companies with the usage of the most contemporary information technology and modern designed organizational structure with highly educated, competent and experienced management. As for every European country, so for Serbia, European Union represents opportunity for stable development and amplification of national competitiveness.

\section{LISBON STRATEGY AND STRATEGY EUROPE 2020}

Ten years ago, Europe's leaders set an ambitious goal of becoming "the most competitive and dynamic knowledge-based economy in the world" by 2010 through a programme of policy initiatives known as the Lisbon Strategy. This included competitiveness-enhancing measures such as the creation of an information society for all, reinforcing European research and development activities, developing a business-friendly start-up environment, promoting social inclusion and enhancing sustainable development (The Lisbon agenda, 2006).

The recent economic crisis has underscored the importance of a competitiveness-supporting economic environment to better enable national economies to absorb shocks and ensure solid economic performance going into the future. To this end, the World Economic Forum has published The Lisbon Review every two years since the European Union first articulated the Lisbon Strategy, assessing Europe's progress towards meeting its ambitious goal. The present - and final - edition takes stock of where Europe stands in this, the deadline year (Europe 2020, 2010). 
Europe 2020 puts forward three mutually reinforcing priorities:

- Smart growth: developing an economy based on knowledge and innovation.

- Sustainable growth: promoting a more resource efficient, greener and more competitive economy.

- Inclusive growth: fostering a high-employment economy delivering social and territorial cohesion.

The EU needs to define where it wants to be by 2020. To this end, the Commission proposes the following EU headline targets:

$-75 \%$ of the population aged 20-64 should be employed.

$-3 \%$ of the EU's GDP should be invested in R\&D.

- The "20/20/20" climate/energy targets should be met (including an increase to $30 \%$ of emissions reduction if the conditions are right).

- The share of early school leavers should be under $10 \%$ and at least $40 \%$ of the younger generation should have a tertiary degree.

-20 million less people should be at risk of poverty.

These targets are interrelated and critical to our overall success. To ensure that each Member State tailors the Europe 2020 strategy to its particular situation, the Commission proposes that EU goals are translated into national targets and trajectories.

The targets are representative of the three priorities of smart, sustainable and inclusive growth but they are not exhaustive: a wide range of actions at national, EU and international levels will be necessary to underpin them. The Commission is putting forward seven flagship initiatives to catalyse progress under each priority theme:

- "Innovation Union" to improve framework conditions and access to finance for research and innovation so as to ensure that innovative ideas can be turned into products and services that create growth and jobs.

- "Youth on the move" to enhance the performance of education systems and to facilitate the entry of young people to the labour market

- "A digital agenda for Europe" to speed up the roll-out of high-speed internet and reap the benefits of a digital single market for households and firms

- "Resource efficient Europe" to help decouple economic growth from the use of resources, support the shift towards a low carbon economy, increase the use of renewable energy sources, modernise our transport sector and promote energy efficiency.

- "An industrial policy for the globalisation era" to improve the business environment, notably for SMEs, and to support the development of a strong and sustainable industrial base able to compete globally

- "An agenda for new skills and jobs" to modernise labour markets and empower people by developing their of skills throughout the lifecycle with a view to increase labour participation and better match labour supply and demand, including through labour mobility.

- "European platform against poverty" to ensure social and territorial cohesion such that the benefits of growth and jobs are widely shared and people experiencing poverty and social exclusion are enabled to live in dignity and take an active part in society.

\section{Rankings and Scores of Non-EU Eastern European Coun- tries by Lisbon goals}

The section analysed how well the countries from Eastern and South-Eastern Europe are meeting the Lisbon goals and highlighted the challenges that remain to be addressed in a variety of areas. They range from official candidate status to potential candidates and also include some countries that have adopted a European Neighbourhood Policy (ENP) Action Plan. This provides a sense of the competitiveness of the greater European region, including a number of countries that may one day join the EU 29.

Table 1 shows the ranks and scores of these countries and, for comparison, also includes the average scores for the EU27, the EU15 members prior to 2004 and the 12 countries that have joined the EU 
since 2004 (the "Accession 12"). As in the case of the EU27, there is considerable variation in performances among these countries overall and across the various dimensions (World Economic Forum, 2010).

In 2010, Montenegro has overtaken Croatia to be the top performer among these countries, albeit just slightly. More generally, there is much consistency in the comparative performances. In particular, the four Balkan countries continue to constitute both the two best performers of the group (Montenegro and Croatia) as well as the two worst performers (Albania and Bosnia and Herzegovina), with the other countries remaining in between, with some small changes in rankings.

Table 1. Rankings and Scores of Non-EU Eastern European Countries

\begin{tabular}{|c|c|c|c|c|c|c|c|c|c|c|c|c|c|c|c|c|c|c|}
\hline \multirow[b]{3}{*}{ Economy } & \multirow{2}{*}{\multicolumn{2}{|c|}{$\begin{array}{l}\text { Final } \\
\text { Index }\end{array}$}} & \multicolumn{16}{|c|}{ Subindexes } \\
\hline & & & \multicolumn{2}{|c|}{$\begin{array}{l}\text { Information } \\
\text { Society }\end{array}$} & \multicolumn{2}{|c|}{\begin{tabular}{|c|} 
Innovation and \\
R\&D
\end{tabular}} & \multicolumn{2}{|c|}{ Liberalization } & \multicolumn{2}{|c|}{$\begin{array}{c}\text { Network } \\
\text { Industries }\end{array}$} & \multicolumn{2}{|c|}{$\begin{array}{l}\text { Financial } \\
\text { Services }\end{array}$} & \multicolumn{2}{|c|}{$\begin{array}{c}\text { Enterprise } \\
\text { Environment }\end{array}$} & \multicolumn{2}{|c|}{$\begin{array}{c}\text { Social } \\
\text { Inclusion }\end{array}$} & \multicolumn{2}{|c|}{$\begin{array}{l}\text { Sustainable } \\
\text { Development }\end{array}$} \\
\hline & Rank & Score & Rank & Score & Rank & Score & Rank & Score & Rank & Score & Rank & Score & Rank & Score & Rank & Score & Rank & Score \\
\hline Montenegro & 1 & 4.19 & 2 & 3.95 & 3 & 3.32 & 2 & 4.34 & 2 & 4.60 & 1 & 4.74 & 6 & 4.32 & 2 & 4.28 & 2 & 3.94 \\
\hline Croatia & 2 & 4.18 & 1 & 4.04 & 2 & 3.36 & 5 & 3.85 & 1 & 5.23 & 3 & 4.34 & 7 & 4.16 & 7 & 3.72 & 1 & 4.70 \\
\hline Azerbaijan & 3 & 4.02 & 4 & 3.67 & 4 & 3.26 & 3 & 4.15 & 6 & 4.16 & 4 & 4.13 & 2 & 4.68 & 1 & 4.50 & 4 & 3.57 \\
\hline Turkey & 4 & 3.85 & 5 & 3.61 & 5 & 3.24 & 1 & 4.39 & 3 & 4.38 & 2 & 4.39 & 5 & 4.46 & 10 & 3.19 & 9 & 3.12 \\
\hline Macedonia, FYR & 5 & 3.79 & 3 & 3.86 & 7 & 2.93 & 4 & 3.95 & 5 & 4.16 & 5 & 4.08 & 3 & 4.58 & 9 & 3.39 & 6 & 3.33 \\
\hline Georgia & 6 & 3.78 & 6 & 3.35 & 9 & 2.79 & 6 & 3.82 & 8 & 3.93 & 7 & 3.69 & 1 & 5.01 & 6 & 3.77 & 3 & 3.89 \\
\hline Ukraine & 7 & 3.62 & 9 & 3.04 & 1 & 3.59 & 10 & 3.48 & 4 & 4.32 & 11 & 3.22 & 9 & 4.08 & 4 & 3.89 & 5 & 3.33 \\
\hline Serbia & 8 & 3.51 & 7 & 3.29 & 6 & 2.95 & 8 & 3.66 & 9 & 3.83 & 8 & 3.68 & 10 & 4.01 & 8 & 3.45 & 7 & 3.19 \\
\hline Armenia & 9 & 3.50 & 11 & 2.70 & 8 & 2.82 & 7 & 3.74 & 7 & 3.94 & 6 & 3.88 & 8 & 4.15 & 5 & 3.79 & 10 & 2.98 \\
\hline Albania & 10 & 3.47 & 8 & 3.13 & 11 & 2.52 & 9 & 3.65 & 11 & 3.46 & 9 & 3.41 & 4 & 4.48 & 3 & 3.94 & 8 & 3.13 \\
\hline Bosnia and Herzegovina & 11 & 3.07 & 10 & 2.86 & 10 & 2.54 & 11 & 3.43 & 10 & 3.73 & 10 & 3.32 & 11 & 3.28 & 11 & 2.69 & 11 & 2.73 \\
\hline EU 27 & - & 4.81 & - & 4.73 & - & 4.23 & - & 4.80 & - & 5.39 & - & 5.05 & - & 4.60 & - & 4.51 & - & 5.16 \\
\hline EU 15 & - & 5.12 & - & 5.06 & - & 4.66 & - & 5.06 & - & 5.80 & - & 5.33 & - & 4.69 & - & 4.78 & - & 5.61 \\
\hline Accession 12 & - & 4.42 & - & 4.32 & - & 3.68 & - & 4.47 & - & 4.88 & - & 4.70 & - & 4.49 & - & 4.19 & - & 4.61 \\
\hline
\end{tabular}

The averages at the bottom of Table 1 show that all countries score lower than the various EU groupings on the overall index, including the average of the 12 more recent members by a reasonable margin. However, top ranked Montenegro outperforms the five lowest-ranked EU members of Greece, Poland, Italy, Romania and Bulgaria. Croatia is on a par with Greece and ahead of the four countries ranked below it. Azerbaijan outperforms Romania and Bulgaria, and Turkey and Macedonia outperform Bulgaria. In other words, the top-performing non-members receive better assessments overall than a number of present members. As mentioned above, the non-EU Balkan countries are spread throughout the ranking of the 11 comparators, occupying the first two positions as well as the last two. Montenegro and Croatia are ranked $1^{\text {st }}$ and $2^{\text {nd }}$ of the group. Montenegro's greatest strengths are in the dimensions of financial services and social inclusion, both areas where it scores above the average of the Accession 12 group of countries. Croatia's main strengths are its network industries and efforts toward sustainable development, where it does better than the Accession 12. With regard to weaknesses, both countries require efforts in improving their enterprise environment, with burdensome regulation and an onerous process required to start businesses, especially in Montenegro (World Economic Forum, 2010).

Within the middle of the ranking are two other Balkan countries: Macedonia $\left(5^{\text {th }}\right)$ and Serbia $\left(8^{\text {th }}\right)$. Macedonia's enterprise environment is its greatest comparative strength, with a score ahead of the Accession 12 countries and just behind that of the EU27, characterized by a good business start-up environment and a relatively supportive regulatory structure. On the other hand, that is Serbia's greatest weakness. However, Serbia get some better marks in terms of creativity, innovation and R\&D.

At the bottom of the table are Albania $\left(10^{\text {th }}\right)$ and Bosnia and Herzegovina $\left(11^{\text {th }}\right)$. Albania's comparative strength is in the enterprise environment, where it is just barely behind the Accession 12 average and not far behind the EU27 score. It is also ranked 3rd out of the 11 countries for efforts towards social inclusion, although its score of 3.94 is well below those of the two strongest performers of the group, Azerbaijan and Montenegro. Beyond these few areas, both countries receive very poor assessments across most other areas, with Bosnia and Herzegovina ranked among the bottom two countries (ranked $10^{\text {th }}$ or $11^{\text {th }}$ for all eight dimensions, and always well below the various EU averages shown for comparison. Given that these countries are potential candidates to join the EU, significant efforts 
must made to bring their performance more in line with EU levels. Turkey is ranked $4^{\text {th }}$ in the table, with some relative strengths balanced by weaknesses in a number of dimensions. Turkey is ranked 1st out of all countries in the table and not far behind the Accession 12 average for the extent of liberalization, with the economy characterized by high levels of competition. Financial services are also relatively well developed, ranked 2nd behind Montenegro out of the 11 countries and ahead of EU members such as Latvia and Romania. The country's enterprise environment is rated close behind that of the Accession 12 average, due to the relative ease of setting up a business in the country. On the other hand, Turkey's competitiveness is held back by its performance in a number of other areas. It has not yet developed an information society that is sufficiently supportive of productivity enhancements, and measures of innovation and R\&D remain below EU standards. More strikingly, it is ranked 9th for efforts towards sustainable development (followed only by Armenia and Bosnia and Herzegovina), and 10th for social inclusion (followed only by Bosnia and Herzegovina), with high unemployment, one of the lowest female participation rates in the workforce, and some concerns about the quality of the educational system. These are areas requiring attention to bring Turkey's competitiveness up to EU standards.

\section{EXISTING INDEXES OF COMPETITIVENESS}

Studies which have set one composite index include World Competitiveness Yearbook (IMD) that is published by International Institute for Management Development (IMD, 2001) once a year analyzing competitiveness of 49 countries and is based on quantitative and qualitative data (consists of the yearly summary by president in each nation) that are classified in 8 groups. Quantitative data are given with coefficient 1 , while summary's data receive 0.64 . IMD (2001) admits that such layout of coefficients is fairly arbitrary, but has used it since 1994 giving coexistence and comparison to data in time row. Serbia is not ranked by this index.

Maybe the most refined attempt to set up adequate coefficients for sub-indicators that contribute composite (compound) index of competitiveness, represent Report of global competitiveness of World economic forum (1999). As in the case of indexes of IMD (2001), such methodology, that is profound regarding inputs by Porter (1999), also includes quantitative as well as qualitative images and classifies them in 8 groups. Allowing coefficient of $3 / 4$ for quantitative data and $1 / 4$ for qualitative data, World economic forum (1999) further gives next coefficients to indicators attained for 8 classification groups: openness, 1/6; authority, 1/6; finances, 1/6; infrastructure, 1/9; technology, 1/9; management, 1/18; workforce, $1 / 6$; and institutions, $1 / 18$. These coefficients are chosen by regression analysis, in which factors are in correlation with economic growth per head of population.

Such approach, which sets up coefficients for independent variables versus preset dependent variables, reminds of Porter's and Stern's (1999) Innovative index, which sets up number of registered patents as one agent of national "innovativeness" and attempts to find calculation for that analyzing one scope of related variables. Problem associated to approaches based on analysis of dependent variables is that they potentially cannot identify other factors of promoters of economic development and competitiveness that are not closely related to dependent variables (Huggins and Izushi, 2001).

Milken Institute New Economy Index measures country performance for regional and sub-state level in United States with scope of factors that refer to activities in high technologies (De Vol, 1999). Study gives one composite index by taking mean value of average for original indicators. Likewise, Atkinson and Gottlieb's (2001) Metropolitan New Economy Index uses assembly of coefficients that vary, but are also arbitrarily set. In Europe, European innovative score list of European commission, which was first time made in 2000, follows innovative capacities of the members of EU and region in EU. Currently score list follows 26 different measures, which estimate performances in the field of human capital, innovative finances, application of knowledge and creative knowledge. Compound innovation index is created using equal coefficients for each indicator (Sajeva et al, 2005).

One of the indicators for measuring of competitiveness of regional economies on global level is Index of competitiveness of knowledge on international level (WKCI), which was first time inducted in 2002 (Huggins and Izushi, 2002). Now in the fourth edition (Huggins et al, 2003; 2004b; 2005), WKCI produces composite measure of knowledge capacity, ability and sustainability of 125 leading regions world wide, comprising Europe, North America and Asia-Pacific. Methodology for creating of the composite is based on analysis of factors and technique known as Analysis of collected data, which does not assign significance based on any dependent variable, but based on association between the variables in deep structure compared to a number of units - in this case regions (Huggins and Izushi, 2002). 


\section{Factors of competitiveness}

There are certain changes in identifying factors that spur economic growth. Traditional theories represent the opinion that companies, regions and countries compete in factors of production, such as workforce and capital, pointing on places that are being developed due to their natural resources or economic infrastructure which encourages companies to locate exactly there. Crucial political decision for the region would be to make each place even more attractive and efficient place for business through tax incentives, business parks and road construction. However, success of some of the most expensive areas in the world points out new theories of economic growth should be reconsidered.

New theory of economic growth attempts to include a certain number of factors that have been previously considered not to belong to economic system such as innovations, technology and education. The work of Paul Romer suggests that technology, as well as knowledge on which it is based, should be inextricably linked with economic system. This was caused due to technological change that appeared as result of designed actions of people that respond to market demands. Romer's model is focused on knowledge, as a basic form of capital, considering it as driver of economic growth, with the application and use of knowledge that creates new technology and processes (Romer, 1990).

In his model, Romer separates knowledge embodied in human capital from products with human application of knowledge (technological change). In other words, human capital is seen through opposing relationship, because person that owns skill or knowledge "can not be on two places in the same time, nor solve more problems in the same time". Consequence of that is that human capital can be personally provided and can be traded on competitive market. On the contrary, technological change does not have opposing relationship, because once established laws regarding science, patents, projects or software can be copied, used and changed again. This endless growth of knowledge creates sources through technology that creates platforms for further innovations and technological change, improves productivity and runs growth. Knowledge and technology can not longer be seen as solely public good, but as partly exclusive good without opposing feature (Romer, 1990).

This model recognizes that investments that enlarge human knowledge give return that increases more and more. That is due to the fact that fixed costs of products and development of technology, that put company ahead of the competition, can be considered as a reason of huge sales volume, resulting in decrease of average costs proportionally to increase of input (Dunford, 2001). Romer concludes that economies with higher stocks of human capital will experience faster growth. His theory supports explanation why growth is not viewed in undeveloped economies despite their large population and workforce.

\section{COMPETITIVENESS OF SERBIA}

It was before mentioned that Serbia is $8^{\text {th }}$ country between countries of Eastern Europe that are not members of EU, by competitiveness regarding the way of achieving Lisbon goals. This low ranging result was affected by number of factors among which specific factors stand out regarding Serbia and world economic crisis during year 2009 that had deep consequences on world economy. Drop in GDP of $4.2 \%$, and especially large drop in industrial production, brought back economies of Europe on the level of ' 90 -s of the last century. That had large influence on the economy of Serbia, because foreign trade with European countries (EU+EFTA+CEFTA) accounts for over $85 \%$ of total exchange of Serbia with the world. Export decreased by $19.8 \%$ in 2009 compared to year 2008, while in the same time period import decreased for $30.2 \%$. Crisis brought to surface basic structural problems of Serbian economy and society. Average increase of GDP by $5.4 \%$ in the last decade was achieved at the cost of two fundamental macroeconomic imbalances, which in not sustainable any more in the next period. Growth until 2009 was based, first of all, on domestic demand, while export share in GDP was only about $25 \%$. About $80 \%$ of economy growth was coming form sectors that produce services (telecommunications, trade, financial services) and in 2010 over $70 \%$ of foreign direct investments was allocated exactly in these three sectors. On the other hand, total consumption was higher for about $25 \%$ compared to GDP achieved. This gap was covered from import that is financed by privatization revenues and external borrowing. All that led to record deficit of foreign trade and current account balance (Serbia 2020, 2010).

Low level of education and investments in human capital, research and technological development, that are basis for fast economy growth, represents big problem. Serbia allocates from the budget around $4.5 \%$ of GDP for education and around $0.3 \%$ of GDP for science per year. However, over 90 $\%$ of those funds go to salaries of employees in all sectors, while smaller part remains for covering 
huge needs of investments in development. Investments in educational and scientific infrastructure and equipment were deficient in the last 20 years, so their quality is on a very low level. Moreover, results expressed through qualification structure of workforce, their skills, number of registered patents etc, are not consistent with market needs which points on inefficient consumption of already scarce resources. It is therefore necessary to accelerate reforms began in these areas, which will contribute focusing of labor market on sectors with higher added value.

Moreover, unpreparedness of population of Republic of Serbia on personal changes in order to enter EU represents barrier that Serbia becomes a member. In other words, only $31 \%$ of citizens are willing to further educate, retrain and develop while only $39 \%$ of citizens are willing to change previous work habits (Graph 1). Undeveloped conscience of population of Republic of Serbia about that every person needs to change i.e. direct towards personal development is a problem that requires, first of all, a lot of time (European Orientation of Serbian Citizens, Trends, 2010).

\section{Graph 1: The extent to which population of Republic of Serbia is willing for personal changes in order to enter $E \boldsymbol{U}$}

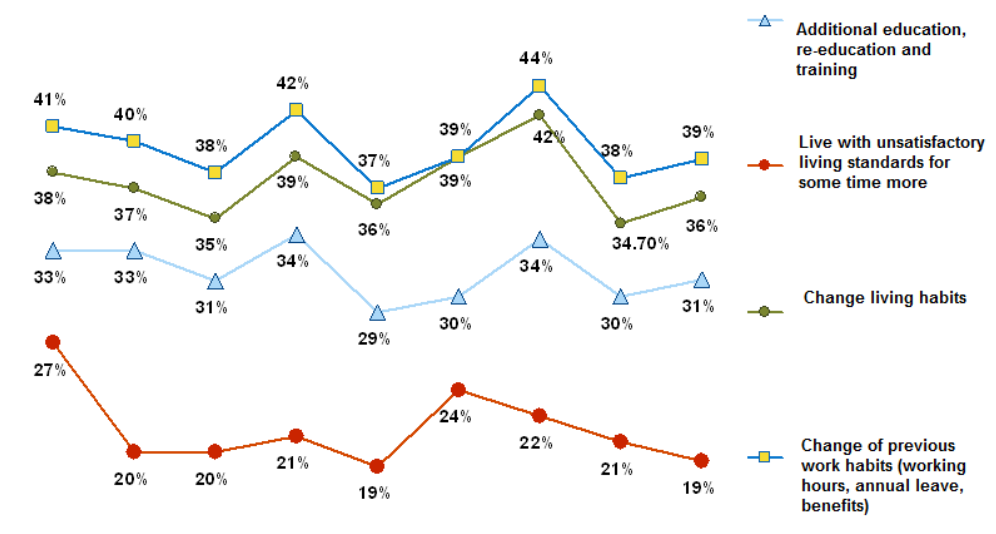

Sept 06 June 07 Nov 07 May 08 Dec 08 May 09 Dec 09 June 10 Dec 10

Increasing lag of Serbia to EU countries regarding availability and quality of infrastructure is a problem. It does not only mean road and rail infrastructure, but also energetic, telecommunication, logistic, utilities infrastructure and all that represents precondition for attracting investments. Strategy Europe 2020 does not longer accentuate development of infrastructure as one of the priorities. That was part of the development in the last decade. If we assume that priorities defined by this strategy will be basis for making the budget for the time period 2014-2020, i.e. if we assume that high funds will not be assigned to infrastructure, it is of high significance that Serbia finishes key infrastructural projects creating preconditions for faster growth and development.

Eventually, Serbia faces serious demographic problems. As in most of the European countries, level of birth is insufficient for reproduction of population in Serbia for the last few decades, causing depopulation and accentuated demographic aging. In the last few years, number of deceased persons is for approximately 30 thousand higher than number of newborn children. One sixth of population is 65 and more years old which classify Republic of Serbia among older countries in the world. In these circumstances share of population of working age also decreases, and coefficient of economic dependence increases. By realization of goals set by this document, faster and more equal growth will be provided with increase of the number of employed people and growth of the standard of population, which will finally positively affect stopping of the trend of population aging and depopulation.

Regarding weaknesses and deficiencies of Serbia and its aim to become a member of EU, Serbia has defined strategic document "Serbia 2020" which is represents the basic elements of socio-economic development of Serbia until year of 2020. It follows the structure proposed and adopted by the European Commission, taking into account the specific conditions of the Republic of Serbia.

In order to successfully implement the goals set by development concept Serbia 2020, it is of key significance fulfillment of two preconditions (Table 2): 
1. Institutional reforms, including constitutional and legal reforms, reform of justice, public administration and security system, by which Serbia would become factor of stability in the region. Necessity of creating this and such precondition confirms also research conducted in public opinion of Serbia in the December of 2010 (Graph 2) (European Orientation of Serbian Citizens, Trends, 2010).

\section{Graph 2: Which reforms in Serbia should be conducted as the most important?}

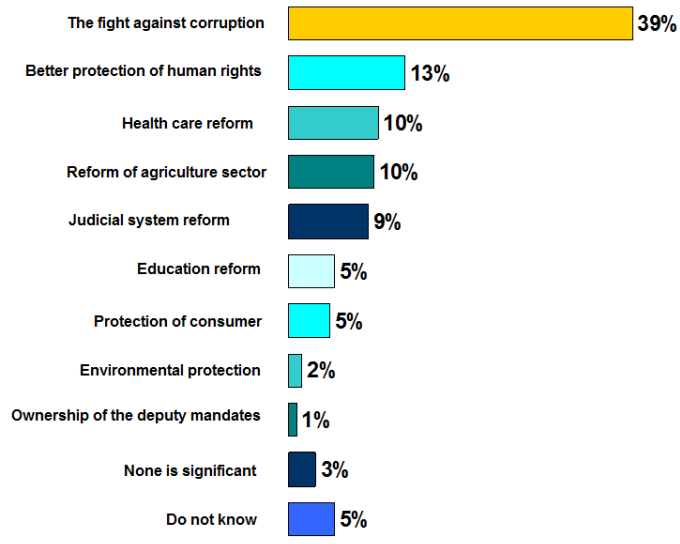

2. Built of infrastructure and definition of spatial development of Serbia in order to create precondition for sustainable economic growth and development.

Table 2. Preconditions and goals for development of Serbia - “Serbia 2020”

\section{CONCLUSION}

The Republic of Serbia is more competitive if the county is closer to EU membership. Criteria on which EU is built i.e. goals set by Lisbon strategy and strategy of Europe 2020 certainly are defined so

\begin{tabular}{|c|c|c|c|c|}
\hline \multicolumn{5}{|c|}{ PRECONDITIONS OF DEVELOPMENT } \\
\hline \multicolumn{5}{|c|}{$\begin{array}{l}\text { Institutional reforms including constitutional and legal, reform of justice, public administration and security system } \\
\text { Built of infrastructure and definition of spatial development of Serbia }\end{array}$} \\
\hline \multicolumn{5}{|c|}{ GOALS OF DEVELOPMENT } \\
\hline $\begin{array}{l}\text { Increase of number of } \\
\text { employed people }\end{array}$ & $\begin{array}{l}\text { Improved human } \\
\text { capital }\end{array}$ & $\begin{array}{l}\text { Investing in } \\
\text { knowledge and } \\
\text { technology }\end{array}$ & $\begin{array}{c}\text { Growth based on } \\
\text { export and rational use } \\
\text { of energy }\end{array}$ & $\begin{array}{l}\text { Social inclusion and } \\
\text { decrease in poverty }\end{array}$ \\
\hline \multirow{3}{*}{$\begin{array}{l}65 \% \text { of population from } 20 \\
-64 \text { years old employed }\end{array}$} & $\begin{array}{l}\text { Less than } 15 \% \text { of } \\
\text { people that have quit } \\
\text { education early }\end{array}$ & \multirow{2}{*}{$\begin{array}{l}2 \% \text { of GDP invested } \\
\text { in research and devel- } \\
\text { opment of which half } \\
\text { from private sector } \\
\text { per year }\end{array}$} & $\begin{array}{l}60 \% \text { of growth of } \\
\text { GDP comes from } \\
\text { sectors that produce } \\
\text { exchangeable goods } \\
\text { and services }\end{array}$ & \multirow{3}{*}{$\begin{array}{l}20 \% \text { less people in } \\
\text { the risk of poverty } \\
\text { (around } 250.000 \text { ) }\end{array}$} \\
\hline & $\begin{array}{l}\text { Less than } 25 \% \text { of } 15- \\
\text { year old with insuffi- } \\
\text { cient level of func- } \\
\text { tional literacy }\end{array}$ & & $\begin{array}{l}30 \% \text { of shares of total } \\
\text { investments in GDP }\end{array}$ & \\
\hline & $\begin{array}{c}30 \% \text { of population } \\
\text { from } 30-34 \text { years old } \\
\text { with tertiary level of } \\
\text { education }\end{array}$ & $\begin{array}{l}6 \% \text { of GDP invested } \\
\text { in development of } \\
\text { education }\end{array}$ & $\begin{array}{l}40 \% \text { higher energy } \\
\text { efficiency with } 20 \% \\
\text { of energy produced } \\
\text { from renewable } \\
\text { sources }\end{array}$ & \\
\hline
\end{tabular}

that EU becomes more competitive. Regarding that, all countries that are not part of EU and wish to be, among which is Serbia, must firstly fulfil certain conditions for entering. Membership in European Union is not a goal by itself, but a mean for realization of long term national strategy of efficient economic development in the function of improvement of life conditions of the whole population, which is realized by achieving of conditions set and goals by EU. Special interests which determine Serbia in 
the direction of European integration are recognized in political, economic and social reasons. Still, one of the most important is certainly that process of association and accession to European Union allows overcoming of

systemic and developmental problems and creates conditions for continual economic growth and prosperity of the citizens of Serbia. Therefore strategic document Serbia 2020 represents concept of development in accordance with "Europe 2020" strategy, which provides coordination of social-economic and political goals of Serbia with the process of accession to European Union.

Competiveness of Serbia should be better monitored. There are a large number of indexes that determine competitiveness; however, a question of their validity raises i.e. adaptation regarding specific conditions of each country. Choosing which index fits best to one particular time period and location is very difficult, so it is important to consider complete situation of the observed area. Serbia, considering its specificities, should better follow its indexes of competitiveness so it could affect them (for example, to use European innovation score list of European commission). In other words, it should emphasize measuring factors that are considered as basic engines of growth in developed economies today, such as innovations, technology and knowledge i.e. human capital, considering that Serbia is more directed towards traditional factors today that affect economic growth.

\section{APPENDIX}

The publication of this scientific work was developed within the project "Improving the Competitiveness of Serbia in the Light of EU Accession Process", Ministry of Science and Environmental Protection of Serbia, no. 47028, for the period year 2011-2014. 


\section{REFERENCES}

***, ,,IMD World Competitiveness Yearbook“, IMD, Geneve, Switzerland, 1997, http://www.imd.ch Bieber, F. (2009), Territory, Identity and the Challenge of Serbia's EU Integration, Centre for International Competetiveness, http://www.cforic.org/pages/wkci.php

Dunford, M. and Smith, A. (2001), Economic restructuring and employment change, in Bradshaw, M. and Stenning, A. (eds) Central and Eastern Europe

EUROPE 2020 A strategy for smart, sustainable and inclusive growth, EUROPEAN COMMISSION, COM (2010) 2020, Brussels, 3.3.2010

European Competiveness Index of Serbia (2009), Republic program, project No.: 114-45100871/2009, 2009, Faculty of technical Sciences, University Novi Sad.

http://www.weforum.org/en/initiatives/gcp/Global\%20Competitiveness\%20Report/PastReports

European Orientation of Serbian Citizens (2010), Trends, European Integration Office of Republic of Serbia

Huggins, R., Izushi, H., Davies, W. and Shougui, L., (2008), World Knowledge Competitiveness Index, Centre for International Competitiveness, pp. 1-4

Kronja, J. (2010), Lisbon strategy - strategy of development of European Union until year 2010, European movement in Serbia

Schwab, K. And Porter, M. (2008), Global Competitiveness Report 2008-2009, World Economic Forum, Geneve, Switzerland, ISBN-13: 978-92-95044-11-1, http://www.weforum.org

Porter, M. and Stern, S. (1999), The New Challenge to America's Prosperity: Findings from the Innovation Index, Council on Competitiveness, Washington DC, USA, ISBN 1-889866-21-0, www.nhrd.net

Storper, M. (1997), The Regional World: Territorial Development in a Global Economy”, New York, Guildford

Petritsch, Wolfgang and Svilanovic, Goran and Solioz, Christophe, eds. Serbia Matters: Domestic Reforms and European Integration. Nomos, Baden-Baden, pp. 65-71. ISBN 978-3-8329-4584-8.

Mirkovic, O. (2009), EU's Regional Policy as an Engine of Economic Development, European Movement

Atkinson, R. and Gottlieb, P. (2001),Metropolitan New Economy Index, Progres Policy Institute, USA $\mathrm{http} / / / \mathrm{www}$. neweconomyindex.org/metro

De Vol, R. (1999), America's High-Tech Economy: Growth, Development, and Risks for Metropolitan Areas, Milken Institute, Santa Monica, USA, http://www.milkeninstitute.org

DeVol, R. (2000), Knowledge-based Economy Index, http://www.milkeninstitute.org/ research/ research.taf?cat $=$ indexes\& function $=$ detail $\& I D=21 \&$ type $=$ NEI

Huggins, R. (2005), Designing A European Competitiveness Index: Measuring The Performance And Capacity Of Europe's Regions And Nations, European Regional Economic Forum, Nova Gorica, Slovenia, Oct. 27-28.

Huggins, R. and Davies, W. (2006), European Competitive Index 2006-07, Robert Huggins Associates Ltd, Pontyprid, U.K., ISBN 1-902829-03-4, http://www.cforic.org

Romer, P. M. (1990), Endogenous Technological Change, Journal of Political Economy, 98, pp.71102.

Dutta, S. and Mia, I. (2008), The Global Information Technology Report 2008-2009: Mobility in a Networked World, World Economic Forum, Geneve, Switzerland, ISBN-13: 978-92-95044-19-7, http://www.weforum.org

Serbia 2009 Progress Report (2009), European Communities, ISBN 978-92-79-13500-2

Serbia 2020: Concept of development of Republic of Serbia until year 2020, http://www.predsednik.rs The Global Competitiveness Report 2008-2009, published by the World Economic Forum, http:// www.weforum.org/pdf/GCR08/GCR08.pdf 
Journal of Global Strategic Management | V. 5 | N. 1 | 2011-June | isma.info | 146-156 | DOI:10.20460/JGSM.2011515819

The Lisbon agenda, ESIB - The National Unions of Students in Europe, Belgium, 2006

The question of Serbia Paris (2005): The European Union Institute, BATT, Judy for Security Studies

The Lisbon Review 2010 Towards a More Competitive Europe?, World Economic Forum, 2010

Theories of European Integration (2002) ROSAMOND, Ben London: Palgrave

Samardžija, V. and Butković, H. (2010), From the Lisbon Strategy to Europe 2020, Institute for International Relations - IMO, Zagreb, ISBN 978-953-6096-53-4, pp. 4-27. 